\title{
entre latidos \\ frenéticos
}

\section{Sandra Regina Pícolo* (ECA-USP)}

\footnotetext{
* Doutora em Ciências da Comunicação pela Escola de Comunicações e Artes (ECA) da Universidade de São Paulo (USP). Atualmente é professora de Graduação e Pós-Graduação da Faculdade Pentágono. Contato: spicolo@uol.com.br
}

Maria Cláudia Araújo apresenta-nos o conto "A humanização do cão", texto em que um animal, na relação com os humanos, possui um lugar de destaque na narrativa. O texto inscreve-se na Literatura Brasileira contemporânea e, como criação estética, integra-se ao contexto sociocultural do século XXI. Enquanto texto artístico serve de testemunho à observação da realidade que o circunscreve.

O conto será observado a partir de dois enfoques: primeiro, o discurso singular do texto, ou seja, a intencionalidade da voz narrativa e as relações entre autor, narrador e discurso e, depois, a manifestação do discurso social de seu tempo, ou seja, de que o conto se apropria e com as quais dialoga.

Com um recorte da realidade, o narrador inicia o relato como uma conversa cotidiana, denotando certa 


\section{opiniães}

proximidade com a oralidade. Já, na primeira linha, há no conto analisado duas figuras ficcionais: o autor suposto e o narrador. Segundo Bakhtin (1988), ocorre a função crítica do autor suposto na criação de um universo ficcional e na sua comunicação com o leitor. Esta voz interpõe-se entre os vários níveis da narração. Observe que antes de iniciar o relato, o autor suposto utiliza a expressão "anos atrás" que pressupõe uma conversa e antecede a narração, na medida em que representa um deslocamento do aqui e agora. Há, portanto, um discurso que simula uma comunicação direta e oral que é, na verdade, indireta e via texto escrito.

Na sequência, ocorre a transferência entre as "entidades ficcionais", ou seja, assume o narrador-personagem o qual irá gerenciar a narrativa. Para Bakhtin (1988), o narrador é um sujeito com existência textual, uma invenção do autor, o que significa que as conexões entre autor e narrador resolvem-se no quadro amplo das opções técnico-literárias.

Seguindo os preceitos de Gérard Genette (1995), no que se refere ao plano da enunciação, todo o relato é conduzido por um narrador autodiegético, que revela sua falta de afinidades com cães, fato que justifica nunca ter "adquirido" um animal de estimação. Paradoxalmente a este fato, objetiva sondar a vida de um deles a fim de narrar suas peripécias. Inicialmente, chama-o de "objeto de estudo", tirando-o da condição de animal - coisificando-o.

Em "o meu protótipo de artigo ficou então no forno", há um incipiente ensaio do que poderia permear todo o texto no que tange a discussão da criação textual. Porém, isto se faz esporadicamente e, o que segue, volta-se mais à discussão da humanização do cão.

Uma cadela foi escolhida para observação. Pertencia a um amigo, porém adoeceu, faleceu e a sondagem nem mesmo começou. A ideia renasce quando Anna Sofia, de 11 anos, sobrinha do narrador, negocia o aluguel de se encontravam cães disponíveis "um deles encontrava-se solitário na gaiola, vexado, cabisbaixo, orelhas murchas". Tal descrição "descoisifica" o animal e, ainda, começa um processo de antropomorfização, na medida em que é comparado ao "aspecto de proletário sem-teto, excluído". Apesar de a literatura ser destituída de qualquer responsabilidade social, a analogia dialoga com problemas sociais do Brasil.

À comiseração e aos apelos da sobrinha, o narrador esmorece: "Só por uma semana". O cão era uma fêmea, a qual, de indefesa e dócil, transformou-se em uma cadelinha agitada e indisciplinada. Nova intervenção do autor suposto com o leitor se faz presente "de onde tirei a ideia de que aquela coisinha fosse adestrada?".

Anna Sofia e mais dois voluntários, Lauri, de 10 anos, e Alan, de 13, participaram da escolha do nome da nova integrante da casa: Laika. Com "os latidos frenéticos... que pareciam ser de gente", paulatinamente vai se humanizando, na proporção que - ao integrar a família - passa a ser tratada como tal. Ao mesmo tempo é taxada de "monstrinho canino" por destruir todo o apartamento.

Um dia, o narrador precisou se ausentar. Não tinha onde deixar a cadelinha e, por esta razão, reuniu sua equipe "em caráter de urgência". Novamente o autor suposto faz a mediação: "que tipo de assembleia era a nossa?" Como numa empresa, o narrador se autonomeia presidente, pois "não entendia absolutamente nada sobre o assunto". Seria uma alfinetada a quem ocupa esta função? Pois bem, a equipe se reúne para o gerenciamento de uma crise. A cadela era a cliente; Alan, o consultor com "soluções proativas" como a indicação do "Pipi Dog: gotas de demarcação sanitária para direcionar o líquido excrementício do cão"; Lauri, o advogado de Laika, o qual teve a ideia de "drogar a cachorra com xarope". Belo advogado... Amanda, a nova integrante, 12 anos, não opinou sobre "a polêmica liberação do uso das drogas". Ao fato, o autor suposto acrescenta: "uma política nata!". Novamente, manifesta-se, simbolicamente, um discurso 


\section{opiniães}

social já que o conto se apropria de temas polêmicos da contemporaneidade no país.

A cadelinha toma o xarope e dorme por umas duas horas, porém, ao acordar, iniciam-se os latidos e a reclamação da vizinhança, que exige a retirada da cadela. Então, de quem não se esperava nenhum traço de afinidade, o narrador, é que vem a defesa mais forte: "puxei a faca e desafiei os vizinhos para uma briga: Laika não sai do prédio! Só se for por cima do meu cadáver!" A justificativa para tal atitude, ainda, era a observação do animal por uma semana. Por esta razão, o narrador chama a vizinhança de intolerante e sem solidariedade. Já é possivel perceber, também, a transformação dele o qual começa a desenvolver sua afetividade em relação à cadelinha.

Uma referência à "Esplanada dos Ministérios", lugar onde, segundo o narrador, Anna tem futuro, é feita quando, ao começarem os problemas, a sobrinha Anna "renuncia ao cargo" de mentora do plano. Então, o narrador transita do "poder executivo para o judiciário" a fim de defender Laika pelos crimes cometidos e indaga: "que crime cometera esse cão da peste? Teria chorado de frio? Fome?", entre outros. E, ocupando a função, agora, de advogado da cadela diz "a ré está sob a fúria de meus pesos e minhas medidas".

Em "restam-me algumas linhas, para pensar sobre o seu despacho, até o final desse artigo", retoma o autor suposto a ideia inicial de elaborar um artigo. Este parecer vem seguido da reflexão "estou farta de Laika e dessa história toda... E ainda nem descobri qual é o sentido da latida de uma cadela em minha vida". Nota-se nestas colocações uma transformação do narrador que começa a prestar atenção e se enternecer, inclusive, em casos apresentados pela mídia acerca de cães maltratados e seus defensores. Indaga-se, também, a respeito do destino de Laika e sobre o fato de ter sido cobaia nesta observação. Retoma até mesmo os formalistas russos e suas teorias sobre o herói e o vilão e, diante disto, tenta decifrar o papel da cadelinha nesta história.
Volta o autor suposto em "deixem-me voltar à lógica do texto". Nova reunião foi realizada pelos membros da "empresa" e ficou acertado deixar Laika em um abrigo. Depois disto, o narrador - sensibilizado - já não concebe a ideia de abandoná-la: "eu estava deixando ir embora um ser que só queria me dar amor". Neste momento reflete sobre suas convicções e sobre sentimentos de outras mulheres. Interroga-se: "Os cães são pessoas? Que ninguém duvide. Rousseau abandonou cinco filhos recém-nascidos mas amava seu cachorrinho de estimação chamado Sultão. É a humanização do cão!"

Enumera, em seguida, enquanto discurso social, os menos favorecidos que "bebem como os cães nos hospitais; nos presídios; nas sarjetas; nas ruas e nas bocas do lixo", e as "pessoas que se calam, à revelia, por não terem nascido com o direito ao grito". Ressalta a fragilidade destas pessoas e, em tempo, pensa na relação destas com os cães que denota "respeito e dignidade".

Depois, num momento introspectivo, o narrador afirma gostar de animais, porém longe deles, independente das discussões a respeito da humanização do cão, que passa pela ciência e pelos benefícios que a convivência traz para as pessoas. Infelizmente, o narrador perdeu a oportunidade de uma experiência transformadora. Vale ressaltar que - com este breve relato - a autora deu ao leitor a chance de refletir sobre diferentes questões as quais vão além do tema a humanização do cão.

\section{Referências bibliográficas}

GENETTE, Gérard. Discurso da Narrativa. $3^{\mathrm{a}}$ ed. Lisboa, Veja, 1995 .

BAKHTIN, Mikhail. Estética da Criação Verbal. São Paulo: Martins Fontes, 1997.

tec, 1988. 